\title{
PEMBERDAYAAN MAHASISWA DALAM PENERAPAN PRINSIP PENGELOLAAN SAMPAH MENGGUNAKAN POLA 4R
}

\author{
Muhsinah Annisa ${ }^{1}$, Fadhlan Muchlas Abrori ${ }^{2}$, Listiani $^{3}$ \\ Program Studi Pendidikan Guru Sekolah Dasar, Universitas Borneo Tarakan ${ }^{1}$ \\ Program Studi Pendidikan Biologi, Universitas Borneo Tarakan ${ }^{2,3}$ \\ Echa.ok@gmail.com ${ }^{1}$, fadhlan1991@gmail.com ${ }^{2}$
}

\begin{abstract}
ABSTRAK
Sampah menjadi masalah yang sangat serius, terutama di daerah Tarakan. Salah satu cara untuk mengelola limbah adalah dengan memberdayakan generasi muda dalam pengelolaan sampah berbasis $4 R$ (mengurangi, menggunakan kembali, mendaur ulang, dan mengganti). Penelitian ini menggunakan pendekatan deskriptif kuantitatif melalui jenis pra-eksperimen. Penelitian ini mengukur pengetahuan, keterampilan dan sikap siswa di Departemen Sekolah Dasar Guru di Universitas Borneo Tarakan. Desain penelitian pra-eksperimen yang dilakukan adalah one gruop pretest-posttest pada pengamatan pengetahuan siswa, dan one shot case study pada pengamatan keterampilan dan sikap. Aspek pengetahuan diperoleh rata-rata sebelum aktivitas 50,625 dan rata-rata setelah aktivitas sebesar 79,13889. Pada aspek keterampilan, hasil yang diperoleh pada skala Likert 1-5 pada indikator pengurangan 4,5; menggunakan kembali 4,25; mendaur ulang 4.12; dan ganti 3.98. Aspek sikap diperoleh pada $80 \%$ dalam afektif, dan 76,5\% dalam konatif.
\end{abstract}

Kata kunci: Sampah, pengelolaan sampah berbasis $4 R$, pemberdayaan

\section{ABSTRACT}

Waste is very serious problem, especially in the Tarakan area. One of the ways to manage waste is through empowering the young generation in $4 R$-based waste managing (reduce, reuse, recycle and replace). This study used a quantitative descriptive approach through the type of preexperiment. This study measures the knowledge, skills and attitudes of students in Department of Elementary Teacher School in University of Borneo Tarakan. The pre-experiment research design carried out was one pretest-posttest group on observing student knowledge, and one shot case study on observing skills and attitudes. aspects of knowledge obtained an average before the activity of 50,625 and the average after activity amounted to 79,13889. On the skill aspect, the results obtained on a 1-5 Likert scale on a reduce of 4.5; reuse of 4.25; recycle 4.12; and replace 3.98. The attitude aspect was obtained at $80 \%$ in affective, and $76.5 \%$ in conative.

Keyword: Waste, 4R-Based waste managing, empowering

\section{PENDAHULUAN}

Sampah merupakan salah satu permasalahan di Indonesia yang sampai saat ini belum menemukan pemecahan masalahnya. Pertambahan jumlah penduduk di Indonesia juga berbanding lurus dengan banyaknya volume sampah yang timbuh dari kegiatan atau aktifitas manusia. Berdasarkan data dari KPUPR (2016) jumlah sampah di Indonesia per tahun sebesar 38,5 juta ton/tahun. Apabila dibagian dengan jumlah keseluruhan masyarakat Indonesia sebanyak 232,8 juta, maka masyarakat Indonesia menghasilkan 0,45 sampah per orang per hari.

Aktifitas manusia setidak menghasilkan 60-70\% sampah organik dan 30-40\% sampah non-organik. Sampah nonorganik yang dihasilkan dari aktifitas manusia sebanyak 14\% merupakan sampah plastik (Purwaningrum, 2016). Jumlah sampah non-organik yang hampir 
mencapai separuh jenis sampah yang dipakai oleh manusia tentunya merupakan bahaya yang perlu diwaspadai, karena sampah non-organik memiliki waktu yang lama untuk diurai.

Tarakan sebagai salah satu kota di Indonesia juga tidak luput dari permasalahan sampah. Abrori dan Listiani (2017) menyatakan jenis sampah yang banyak ditemukan khususnya di pesisir kota Tarakan sebanyak 50\% adalah sampah plastik yang merupakan sampah non-organik. Banyak sampah plastik terutama di daerah pesisir akan mengganggu ekosistem di daerah pesisir itu sendiri, maupun di daerah perairan.

Penyelesaian masalah sampah salah satunya dengan merangkul generasi muda dalam pemupukan cinta lingkungan melalui pendidikan lingkungan hidup. Pendidikan lingkungan hidup dapat diartikan sebagai proses menanamkan kesadaran dan peduli lingkungan yang nantinya kan memunculkan masyarakat yang memiliki pengetahuan, keterampilan, sikap, tingkah laku, motivasi dan komitmen terhadap permasalahan lingkungan (Suaedi dan Tantu, 2016).

Cara pemberdayaan generasi muda dalam kegiatan pendidikan lingkungan hidup adalah melalui pengelolaan sampah. Pengelolaan sampah di Indonesia diatur dalam Undang-Undang no.18 Tahun 2008. Pada undang-undang tersebut diatur pengelolaan sampah sebagai kegiatan yang sistematis, menyeluruh, dan berkesinambungan meliputi pengurangan dan penanganan sampah. Pada skala rumah tangga, pemerintah juga mengeluarkan Peraturan Pemerintah no. 81 tahun 2012. Banyaknya peraturan terkait sampah tidak selalu memberikan dampak yang positif, karena peraturan tersebut hanya sebagai "formalitas" dan masyarakat tetap membuang sampah sembarangan. Langkah meminimalisir semakin parahnya permasalahan sampah, maka perlu dilakukan kegiatan pengolahan sampah.

Pengelolaan sampah khususnya di daerah Tarakan, perlu dilakukan sedini dan secepat mungkin. Hal ini karena kapasitas TPA di daerah Tarakan sudah terlalu over dan tidak lagi mampu menampung jumlahh sampah. Salah satu cara pengelolaan yang dapat diterapkan khususnya pada generasi muda adalah pengelolaan sampah berbasis $4 \mathrm{R}$ (recycle, reuse, reduce, dan replace), yaitu kegiatan memperlakukan sampah dengan cara, menggunakan kembali, mengurangi, mendaur ulang, dan menggantikan.

Berdasarkan hal tersebut, perlu adanya pembelajaran lingkungan hidup yang dapat diterapkan secara nyata di lingkungan sekitar, yaitu menerapkan pembelajaran PLH dengan melakukan praktek lapangan pengelolaan sampah dengan metode $4 \mathrm{R}$. Tujuan kegiatan yang akan dilakukan adalah penerapan pendidikan lingkungan hidup dengan praktek lapangan pengelolaan sampah dengan metode $4 \mathrm{R}$ pada mahasiswa PGSD Universitas Borneo Tarakan.

\section{METODE}

Penelitian ini menggunakan pendekatan deskriptif kuantitatif melalui jenis pra-experiment. Penelitian ini mengukur pengetahuan, keterampilan dan sikap mahasiswa PGSD Universitas Borneo Tarakan. Desain penelitian praexperiment yang dilakukan adalah one grup pretest-postest pada pengamatan pengetahuan, dan one shot case study pada pengamatan keterampilan dan sikap.

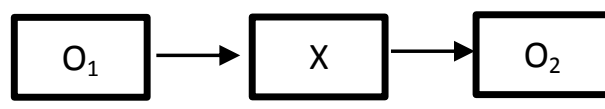

Gambar 1. Desain One Grup PretestPostest

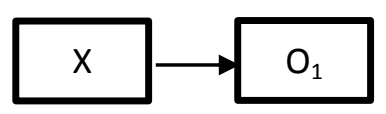

Gambar 2. Desain One Shot Case Study

Pengumpulan data terkait pengetahuan dilakukan melalui lembar tes yang dilaksanakan sebelum dan setelah pelaksanaan kegiatan pengelolaan sampah. 
Pengumpulan data terkait keterampilan dan sikap dilakukan dengan lembar pengamatan, hasil karya mahasiswa, dan kuesioner terkait sampah Data sekunder untuk mendukung hasil dari kegiatan adalah dokumentasi terkait pengelolaan sampah berbasis $4 \mathrm{R}$ yang dilakukan oleh mahasiswa. Analisis data untuk kognitif menggunakan uji $\mathrm{t}$ sampel berpasangan, sementara untuk data psikomotorik dan afektif menggunakan statistik deskriptif. Kriteria keberhasilan dalam penelitian ini apabila nilai rata-rata pada setiap aspek berada diatas nilai 75 . Khusus pada aspek kognitif dikatakan berhasil apabila terdapat perbedaan rata-rata hasil kognitif antara sebelum dan sesudah penelitian.

Kegiatan dilakukan dalam jangka waktu dua bulan dimulai dari tanggal 2 Februari sampai 25 Maret 2018. Kegiatan dilakukan di Universitas Borneo Tarakan dan Pantai Amal Tarakan. Kegiatan diikuti oleh 72 orang mahasiswa.

\section{HASIL}

\section{Aspek Pengetahuan}

Pengukuran aspek pengetahuan mahasiswa melalui penggunaan tes sebelum dan sesudah pelaksanaan kegiatan. Hasil rata-rata dan standar deviasi terkait tes oleh mahasiswa tergambar pada Tabel 1.

Berdasarkan hasil tes juga dilakukan pengujian dengan uji $t$ sampel berpasangan untuk mengetahui adanya perbedaan antara data sebelum pelaksanaan kegiatan dan setelah pelaksanaan kegiatan. Hasil dari uji $t$ sampel berpasangan disajikan pada Tabel 2. Hasil uji t pada aspek pengetahuan mahasiswa didapatkan hasil pada Sig. (2tailed) sebesar $0.000<0.05$ yang berarti terdapat perbedaan pada aspek pengetahuan pada sebelum dan setelah pelaksanaan kegiatan.

Tabel 1. Hasil Tes Mahasiswa

\begin{tabular}{lrr}
\multicolumn{1}{c}{ Tes } & \multicolumn{1}{c}{ Rata-Rata } & \multicolumn{1}{c}{ Std. Deviasi } \\
\hline Sebelum & 50.625 & 11.62615 \\
\hline Sesudah & 79.13889 & 6.503099 \\
\hline
\end{tabular}

Tabel 2. Hasil Uji T Berpasangan

\begin{tabular}{|c|c|c|c|c|c|c|c|c|c|}
\hline & \multicolumn{5}{|c|}{ Paired Differences } & \multirow[b]{3}{*}{$t$} & \multirow[b]{3}{*}{ df } & \multirow[b]{3}{*}{ Sig. (2-tailed) } \\
\hline & & \multirow[b]{2}{*}{ Mean } & \multirow[b]{2}{*}{ Std. Deviation } & \multirow{2}{*}{$\begin{array}{l}\text { Std. Error } \\
\text { Mean }\end{array}$} & \multicolumn{2}{|c|}{$\begin{array}{l}\text { 95\% Confidence Interval of the } \\
\text { Difference }\end{array}$} & & & \\
\hline & & & & & Lower & Upper & & & \\
\hline
\end{tabular}

\section{Aspek Keterampilan}

Aspek psikomotorik diukur melalui lembar pengamatan kegiatan yang dilakukan oleh dosen terhadap kegiatan siswa. Lembar pengamatan kegiatan menggunakan penilaian untuk kinerja mahasiswa yang dibagi setiap kelompok dalam pelaksanaan setiap kegiatan dalam tahapan pengelolaan sampah berbasis $4 \mathrm{R}$ menggunakan skala likert 1-5. Hasil dari penilaian aspek psikomotorik ditampilkan pada Tabel 3.

Tabel 3. Penilaian Aspek Psikomotorik dalam Kegiatan Pengelolaan Sampah

\begin{tabular}{lllcc}
\hline No & Kegiatan & \multicolumn{1}{c}{ Deskripsi Kegiatan } & $\begin{array}{c}\text { Skala } \\
\text { Likert }\end{array}$ & $\begin{array}{c}\text { Persentase } \\
(\%)\end{array}$ \\
\hline 1. & Reduce & $\begin{array}{l}\text { Mengurangi sampah melalui penghematan penggunaan } \\
\text { barang yang akan menghasilkan sampah, dan mengurangi } \\
\text { tumpukan sampah yang berada di lingkungan masyarakat }\end{array}$ & 4.5 & 90 \\
\hline 2. & Reuse & $\begin{array}{l}\text { Mengurangi penggunaan sampah yang masih bisa } \\
\text { digunakan kembali }\end{array}$ & 4.25 & 85
\end{tabular}




\begin{tabular}{lllcc}
\hline No & Kegiatan & \multicolumn{1}{c}{ Deskripsi Kegiatan } & $\begin{array}{c}\text { Skala } \\
\text { Likert }\end{array}$ & $\begin{array}{c}\text { Persentase } \\
(\%)\end{array}$ \\
\hline 3. & Recycle & $\begin{array}{l}\text { Mendaur ulang sampah menjadi barang baru atau barang } \\
\text { lain }\end{array}$ & 4.12 & 82,4 \\
\hline & & $\begin{array}{l}\text { Sosialisasi kepada warga untuk mengurangi sampah } \\
\text { melalui kegiatan mengganti barang yang memiliki resiko } \\
\text { menjadi sampah yang sulit terurai kepada barang lain } \\
\text { yang gampang terurai }\end{array}$ & 3.98 & 79.6 \\
4. & Replace & & & \\
\hline
\end{tabular}

Pada aspek keterampilan selain dilakukan penilaian terkait kegiatan pembersihan sampah, juga dilakukan penilaian pada hasil barang daur ulang yang dikembangkan oleh mahasiswa menjadi barang berguna (Gambar 3 dan 4). Kegiatan pembersihan dalam tahapan reduce dilakukan di Pantai Amal Tarakan. Tahapan selanjutnya juga dilakukan penyeleksian sampah yang bisa digunakan kembali (reuse). Mahasiswa juga

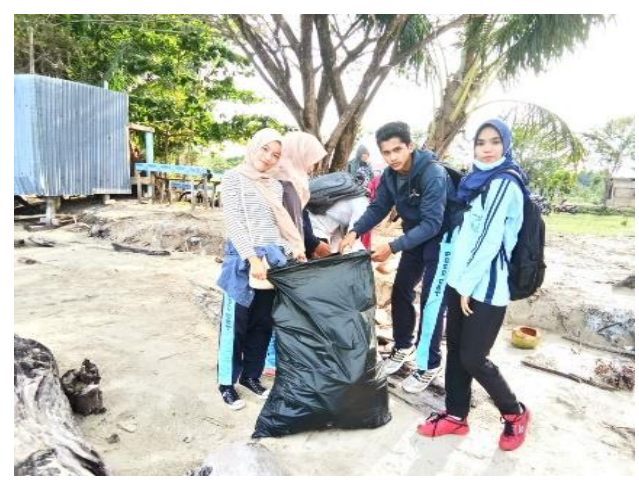

a.

Gambar 3. Kegiatan Pengumpulan sampah di Pesisir Pantai: (a) Pengumpulan sampah (b) Pembersihan di pesisir pantai

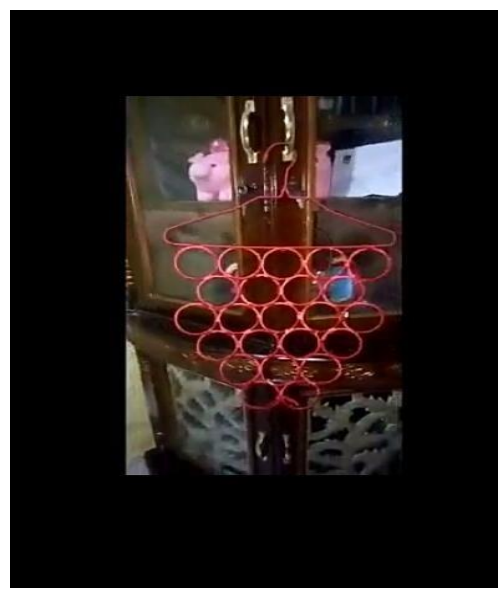

a.

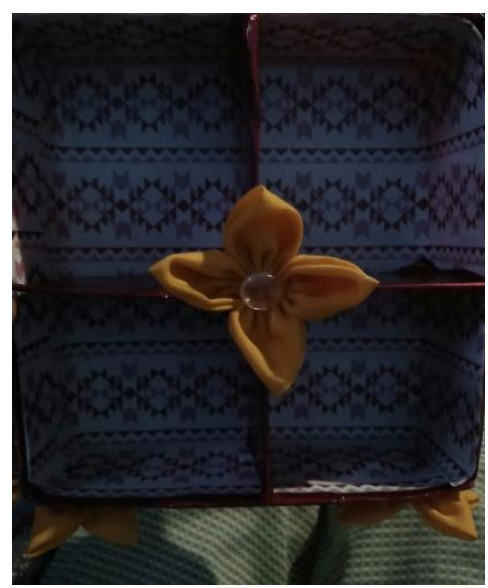

b.

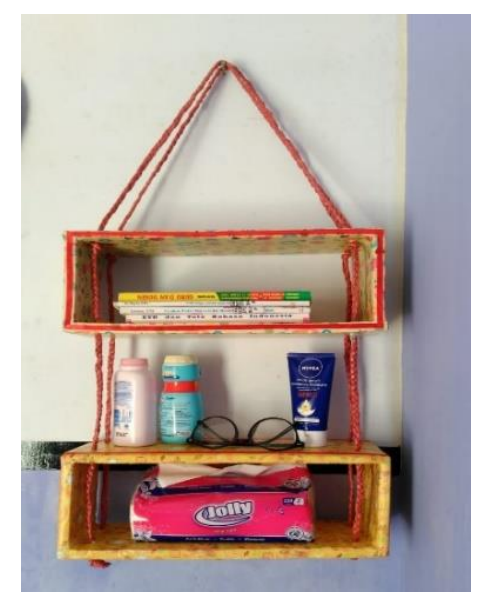

c.

Gambar 4. Jenis Hasil Daur Ulang Sampah: a) gantungan jilbab; b) Box aksesoris;

c) hiasan dinding. 


\section{Aspek Sikap}

Setelah dilakukan pengukuran terkait aspek pengetahuan dan keterampilan. Aspek terakhir yang diukur adalah aspek sikap. Aspek sikap diukur dengan kuesioner sikap terkait cinta lingkungan dan pengelolaan sampah. Aspek sikap dibagi menjadi afektif dan konatif. Afektif merupakan penilaian berdasarkan perasaan mahasiswa. Konatif merupakan gambaran tindakan mahasiswa. Kuesioner menggunakan skala likert 1-5 yang kemudian dipersentasekan untuk melihat gambaran sikap mahasiswa terkait pengelolaan sampah. Hasil dari pengukuran ditampilkan pada Gambar 5.

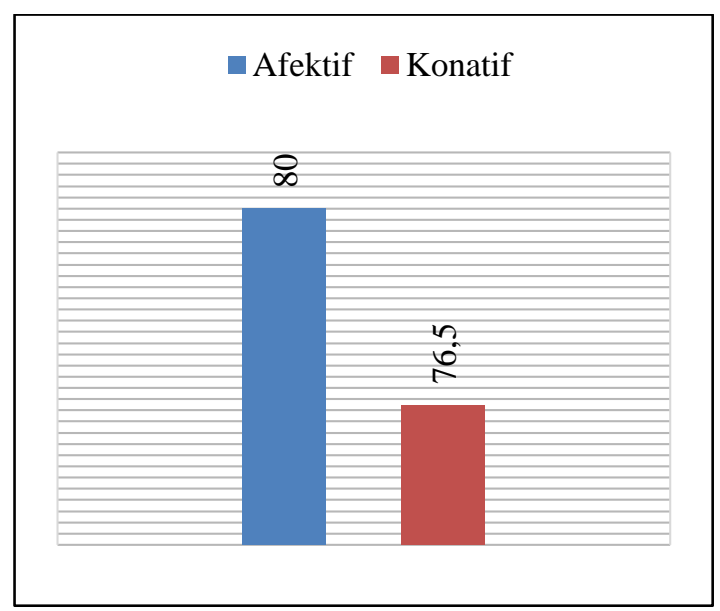

Gambar 5. Persentase Pengukuran Aspek Sikap

\section{PEMBAHASAN}

\section{Aspek Pengetahuan}

Kegiatan pengelolaan sampah berbasis $4 \mathrm{R}$ dilakukan tes sebelum pelaksanaan kegiatan untuk mendapatkan gambaran pengetahuan mahasiswa terkait pengelolaan sampah. Kegiatan ini juga terdapat kegiatan tatap muka dalam matakuliah Pengantar Lingkungan Hidup yang berisi materi pengelolaan sampah meliputi: definisi sampah, jenis-jenis sampah, bahaya sampah, manfaat sampah, karakteristik sampah, pengelolaan sampah berbasis $4 \mathrm{R}$ serta peran dan peraturan kebijakan pemerintah dalam pengelolaan sampah. Kegiatan pembelajaran yang dilakukan dosen juga menungaskan mahasiswa untuk berdiskusi dalam kelompok kecil tentang pngelolaan sampah. Mahasiswa saling berdiskusi tentang bahaya sampah yang ada di kota Tarakan.

Berdasarkan hasil tes mahasiswa pada Tabel 1, didapatkan kenaikan ratarata sebelum dan sesudah kegiatan. Hal ini menunjukkan peningkatan pengetahuan mahasiswa terkait pengelolaan sampah. Data juga menunjukkan kualitas yang baik karena adanya penurunan standar deviasi pada sebelum dan sesudah. Standar deviasi yang kecil menunjukkan juga sebaran dan rentang nilai setiap mahasiswa kecil dan baik (Jaya dan Ardat, 2013). Berdasarkan penilaian dengan uji $t$ berpasangan (Tabel 2) didapatkan hasil ada perbedaan yang menunjukkan terjadinya perbedaan signifikan terkait aspek pengetahuan sebelum dan setelah pelaksanaan kegiatan.

Pengetahuan terkait sampah perlu diperkenalkan semenjak awal kepada mahasiswa, karena minimnya pengetahuan terkait sampah akan berdampak pada kurangnya kesadaran dalam pengelolaan sampah khususnya pada tahap awal, yaitu pemilahan. Penelitian oleh Susanto dkk (2010) terkait tingkat pengetahuan masyarakat dan cara pengelolaan sampah, didapatkan hasil bahwa gaya hidup warga terkait pengelolaan sampah dipengaruhi oleh pengetahuan warga terhadap sampah itu sendiri. Penelitian tersebut menyatakan $84 \%$ responden tidak bisa mengelola sampah dengan baik. Berdasarkan hal ini pengetahuan perlu ditekankan kepada mahasiswa sebelum memulai kegiatan pengelolaan sampah.

\section{Aspek Keterampilan}

Aspek keterampilan merupakan aspek yang paling penting dalam kegiatan ini. kegiatan pengelolaan sampah merupakan yang melibatkan keterampilan mahasiswa sehingga sebagian besar gambaran kegiatan tergambar di aspek ini. Berdasarkan pengukuran hasil pada aspek keterampilan di Tabel 3 didapatkan kesimpulan setiap tahapan didapatkan hasil yang baik dan berada di atas poin 4 (skala 5), kecuali pada replace. Tahap reduce, 
reuse dan recycle dilakukan mahasiswa secara baik karena melalui terjun langsung ke lapangan.

Tahapan awal dimulai dari mahasiswa mengidentifikasi daerah-daerah yang terdapat timbunan sampah serta perilaku masyarakat tertentu yang masih sering membuang sampah di jalan dan laut. Berdasarkan hasil identifikasi mahasiswa Pantai Amal merupakan tempat yang memiliki banyak tumpukan sampah karena merupakan kawasan wisata dan juga terdapat beberapa pemukiman warga di daearah tersebut. Ketika tempat penampungan sampah tidak dapat menampung lagi jumlah sampah yang terus bertambah setiap saatnya, maka akan menimbulkan masalah di bidang kesehatan maupun bidang lainnya.

Dalam hal konsep pengelolaan sampah, mahasiswa sudah mengetahui pengelolaan sampah dengan menggunakan metode 4R, yaitu reduce, reuse, recycle dan replace. Mahasiswa mulai menerapkan salah satu aspek dari pengelolaan sampah mengacu $4 \mathrm{R}$, yaitu reduce dan reuse. Dalam kegiatan seharihari mereka berusaha megurangi penggunaan plastik dengan cara membawa botol minuman dan makanan sendiri. Penggunaan kantong platik dan sterofoam sudah mulai dikurangi. Terkadang mahasiswa membawa makanan bekal makan siang di kampus dengan membawa bekal dari rumah. Selain hal tersebut aksi mahasiswa di masyarakat melalui pemungutan sampah yang banyak berserakan khususnya di daerah Pantai Amal.

Pengelolaan sampah di lingkungan rumah juga telah dilakukan oleh mahasiswa, dengan bantuan petugas yang ditugaskan oleh RT dalam mengambil sampah yang telah dibuang warga pada tempatnya. Pengelolaan sampah dengan mendaur ulang juga dikakukan yaitu dengan menggunakan bahan bekas seperti botol, kaleng cat yang bisa digunakan sebagai pot tanaman. Mahasiswa juga mengembangkan barang lain melalui pendaurulangan sampah plastik seperti pada Gambar 3.

Salah satu kendala yang dihadapi dalam pengelolaan lingkungan diantaanya yaitu masih kurangnya pengetahuan masyarakat akan pengelolaan sampah, khususnya kurangnya sosialisasi mahasiswa dalam mengajak masyarakat menggantikan kantong plastik (replace) sehingga data pada tahapan ini hanya diperoleh nilai pada aspek keterampilan di bawah 4. Kendala ini mungkin terjadi karena masyarakat sekitar sudah terbiasa menggunakan kantong plastik dan tidak adanya pelatihan terkait pengelolaan sampah di masyarakat sebelumnya. Sumunar dkk. (2008) menyatakan bahwa untuk memupuk jiwa sadar lingkungan di masyarakat, perlu adanya kegiatan pengelolaan sampah melalui proses pelatihan dan sosialisasi. Pelatihan perlu ditekankan melalui metode ceramah dan sosialisasi khususnya sampah rumah tangga. Kegiatan perlu dilakukan berkesinambungan sehingga lambat laun masyarakat sadar akan pentingnya menjaga lingkungan.

\section{Aspek Sikap}

Aspek sikap untuk pengelolaan sampah mahasiswa diukur berdasarkan afektif dan konatif mahasiswa. Berdasarkan data pada grafik di Gambar 3 didapatkan hasil untuk aspek afektif didapatkan nilai sebesar $80 \%$ dan konatif sebesar $76.5 \%$. Tingginya nilai afektif merupakan dampak selama dilakukan kegiatan pengelolaan sampah dalam pendidikan lingkungan hidup. Aspek konatif sedikit lebih rendah dibandingan aspek afektif karena menuntut pertimbangan dalam melakukan sesuatu, terutama menantukan tindakan terkait pengelolaan sampah.

Saputra dan Mulasari (2017) menyatakan bahwa pembentukan sikap terkait cinta lingkungan dalam pengelolaan sampah dipengaruhi oleh beberapa faktor, diantaranya: pengalaman personal, kebudayaan setempat, media massa, lembaga pendidikan, lembaga agama dan 
emosional. Berdasarkan faktor-faktor tersebut pemupukan sikap cinta lingkungan dalam pengelolaan sampah sangat tepat diterapkan melalui pendekatan pendidikan karena dalam pendidikan sikap (afektif dan konatif) selalu berjalan bersamaan dalam proses pembelajaran itu sendiri. Hasil akhir dari pendidikan adalah pemupukan perasaan cinta lingkungan (afektif) dan penerapan perasaan itu diterapkan dalam tindakan pengelolaan sampah (konatif).

\section{KESIMPULAN}

Hasil kegiatan ini pada aspek pengetahuan, keterampilan dan sikap didapatkan hasil yang baik, karena ratarata nilai akhir di atas 75 . Pada aspek pengetahuan didapatkan rata-rata sebelum kegiatan sebesar 50,625 dan rata-rata setelah kegiatan sebesar 79,13889. Pada aspek keterampilan didapatkan hasil dalam skala likert skala 1-5 pada kegiatan reduce sebesar 4,5 (90\%); reuse sebesar 4,25 (85\%); recycle sebesar 4,12 (82,4\%); dan replace sebesar 3,98 (79,6\%). Aspek sikap didapatkan hasil sebesar $80 \%$ pada afektif, dan $76,5 \%$ pada konatif.

\section{DAFTAR PUSTAKA}

Abrori, F. M., \& Listiani, L. (2017). Pemberdayaan Mahasiswa Dalam Menjaga Kebersihan Pantai Amal Baru Melalui Kegiatan Pembersihan Sampah. JPMB (Jurnal Pengabdian Masyarakat Borneo), 1(1), 49-52.

Jaya, I., \& Ardat (2013). Penerapan Statistik untuk Pendidikan. Bandung: Citapustaka Media Perintis.

Kementerian Pekerjaan Umum dan Perumahan Rakyat (KPUPR). (2016). Hari Peduli Sampah Nasional Semua Bergerak Tanggulangi Masalah Darurat Sampah. Buletin Cipta Karya Edisi 02 XIV : 4 -8

Peraturan Pemerintah Nomor 81 Tahun 2012 Tentang Pengelolaan Sampah Rumah Tangga dan Sampah Sejenis Sampah Rumah Tangga.
Purwaningrum, P. (2016). Upaya mengurangi timbulan sampah plastik di lingkungan. Indonesian Journal of Urban and Environmental Technology, 8(2), 141-147.

Saputra, S., \& Mulasari, S. A. (2017). Pengetahuan, Sikap, dan Perilaku Pengelolaan Sampah pada Karyawan di Kampus. Jurnal Kesehatan Masyarakat, 11(1), 22-27.

Suaedi \& Tantu, H. (2016). Pembelajaran Pendidikan Lingkungan Hidup. Bogor: IPB Press.

Sumunar, D.R.S., Khotimah, N., \& Hadi, B.S. (2008). Pelatihan dan Sosialisasi Pengelolaan Sampah Rumah Tanga Berbasis Budaya Terhadap Guru Sekolah Dasar di Kecamatan Wirobrajan (Menuju Kota JOgja Green and Clean). Lapaoran Pengabdian Kepada Masyarakat. Universitas Negeri Yogyakarta.

Susanto, R., Lailatul, N. M \& Pahroni, R. (2010). Hubungan pengetahuan terhadap pengelolaan sampah Organik dan non organik pada masyarakat RW 03 Sumbersari Malang. Jurnal Keperawatan, 1(1) : 32-38.

Undang-undang No. 18 Tahun 2008 tentang Pengelolaan Sampah. 